\begin{tabular}{|c|c|}
\hline$\beth$ & $\begin{array}{c}\text { International Journal of Current Research } \\
\text { and Academic Review }\end{array}$ \\
\hline $\begin{array}{l}\text { UBLII } \\
\text { UT }\end{array}$ & $\begin{array}{c}\text { ISSN: 2347-3215 (Online);,', Nolume 5, Number } 1 \text { (January-2017) } \\
\text { Journal homepage: http://www.ijcrar.com }\end{array}$ \\
\hline
\end{tabular}

doi: http://dx.doi.org/10.20546/ijcrar.2017.501.013

\title{
Health Risk Assessment of Heavy Metals for Population via Consumption of Vegetables Collected from Khassa River, Kirkuk City, Northern Iraq
}

\author{
Sabah A. Ismail and Shwan M. Rashid* \\ Applied Geology Department, College of Science, Kirkuk University, Iraq \\ *Corresponding author.
}

\begin{abstract}
The present study was carried out to investigate heavy metal accumulation inthirtythree soil samples from different depths and six vegetable samples and to assess the human health risks of vegetable consumption. Four vegetable types (cress, leek, chard and celery) were irrigated with wastewater cultivated on farmland contaminated with heavy metals $(\mathrm{Cu}, \mathrm{Pb}, \mathrm{Zn}$, and As) from Khassa river of Kirkukcity. The order of heavy metal concentration was found in $\mathrm{Zn}>\mathrm{Cu}>\mathrm{Pb}>\mathrm{As}$ in vegetable samples and $\mathrm{Zn}$ $>\mathrm{Cu}>\mathrm{Pb}>\mathrm{As}$ was observed in soil samples. The health risk assessment methods include target hazard quotient (THQ) and hazard quotient (HQ) were used to assess the human health risks posed by heavy metals through vegetable consumption.
\end{abstract}

\section{Article Info \\ Accepted: 10 January 2017 \\ Available Online: 20 January 2017}

Keywords

Heavy metal, Health risk,

Vegetables, Wastewater.

\section{Introduction}

Use of wastewater to irrigate agricultural lands is one of common practice in suburban and industrial areas in many parts of the world (Sharma et al., 2007; Gupta et al., 2008). Wastewater irrigation leads to accumulation of heavy metals in the soil (Singh et al., 2004; Mapanda et al., 2005). The increasing demands for food and food safety has drawn the attention of researchers to the risks associated with consumption of contaminated foodstuffs i.e. pesticides, heavy metals and or toxins in vegetables (Mello, 2003; Abdollatif et al., 2009).

Heavy metals contamination is a major problem of our environment and they are also one of the major contaminating agents of our food supply (Khair, 2009). Wastewater carries appreciable amounts of trace toxic metals (Pescod, 1992; Yadav et al., 2002) which often leads to degradation of soil health and contamination of food chain mainly through the vegetable grown on such soils (Rattan et al., 2002).

The toxic elements accumulated in organic matter in soils are taken up by growing plants and lastly exposing humans to this contamination (Khan et al., 2008). Lead is the most toxic and the most abundant heavy metal in food. Excessive accumulation of these heavy metals in human bodies creates the problems like cardiovascular, kidney, nervous and bone diseases (Jarup, 2003; WHO, 1992; Steeland et al., 2000). It is known that serious systemic problems can develop as a result of increased accumulation of dietary heavy metals such as cadmium and lead in the human body. However, very few studies have investigated multiple heavy metals $(\mathrm{Cu}, \mathrm{Pb}, \mathrm{Zn}$ and As) in soils. Therefore, in this study, field experiments were carried out on $\mathrm{Cu}, \mathrm{Pb}, \mathrm{Zn}$ and As contaminated farmland from Khassa river in Kirkuk city, northern Iraq, where six vegetable samples (four vegetable types) were 
used in the trials. The main purposes of this study were ; (1) to investigated the concentration of heavy metals $(\mathrm{Cu}$, $\mathrm{Pb}, \mathrm{Zn}$ and $\mathrm{As}$ ) in soil irrigated by wastewater, (2) effect of wastewater irrigation on the vegetable grown in Kirkuk area, northern Iraq, (3) to assess the health risks of vegetable consumption on residents (adults and children).

\section{Method of Study}

Thirty-three soil samples from different depths $(0-15 \mathrm{~cm}$ depths) and six vegetable samples were collected by hand trowel using polyethylene sacs to avoid accidental contamination and these samples were analyzed by ICPMS techniques at Acme Lab. /Canada for detail geochemical. The edible parts of the vegetable samples were washed by distilled water many times to remove all dusts and soil from it and these samples were dried in oven under $60 \mathrm{C}^{\circ}$ for 3-5 hours. The accuracy and precision of metal analysis were ensured through replicate analyses samples against standards reference material (SRM) for all the heavy metals. The results were found to be within $\pm 2 \%$ of certified values, thus demonstrating the accuracy of our findings.

\section{Results and Discussion}

\section{Heavy metal in soil}

The concentrations of heavy metals in soil $(\mathrm{mg} / \mathrm{kg})$ of the study area are presented in Table 1, and ranged from 20 to 66 for $\mathrm{Cu}, 3$ to 61 for $\mathrm{Pb}, 3$ to 8 for As, and 44 to 217 for $\mathrm{Zn}$. The highest concentration recorded in the study soil samples was for $\mathrm{Zn}$ followed by $\mathrm{Cu}, \mathrm{Pb}$ and $\mathrm{As}$. Concentration level of $\mathrm{Cu}$ was lower than the international standard, except samples10 and 11 were higher. Few samples (DEFRA, 1999) show high levels of $\mathrm{Pb}$, higher than the international standard. The high concentration of $\mathrm{Pb}$ is due to pollution by wastewater irrigation process (Hutchinson et al., 1987). Concentration level of As was lower than the international standard in all soil samples. Concentration level of $\mathrm{Zn}$ was lower than the international standard, except samples10, 11 and 33 were show higher. Highest deposition of $\mathrm{Zn}$ in the study soil samples might be due to result from long-term applications of wastewater that may contaminate soil (Veeresh et al., 2003).

\section{Heavy Metal in Vegetables}

The toxic trace elements concentrations in edible parts of vegetables are listed in Table 2, and shown in Figure 1.
The concentration of trace elements $(\mathrm{mg} / \mathrm{kg})$ ranged from 44.3 to 100.37 for $\mathrm{Cu}, 4.03$ to 16.04 for $\mathrm{Pb}, 1$ to 3.4 for As, and 187.9 to 870.0 for $\mathrm{Zn}$. The levels of $\mathrm{Pb}$, As and $\mathrm{Zn}$ in all vegetable samples were higher than the safe limit of WHO. The average concentration of $\mathrm{Cu}$ was $69.815 \mathrm{mg} / \mathrm{kg}$ and it was with the safe limit of WHO, except in leek and chard were show high level concentrations (87.39 and $100.37 \mathrm{mg} / \mathrm{kg}$; respectively).The concentrations of $\mathrm{Pb}$ and $\mathrm{As}$ were highest in cress $(16.04 ; 3.4 \mathrm{mg} / \mathrm{kg}$, respectively). The highest concentration of $\mathrm{Zn}$ was found in cress $(870.2$ $\mathrm{mg} / \mathrm{kg})$ followed by celery-2 $(187.9 \mathrm{mg} / \mathrm{kg})$.

\section{Transfer Factors for Heavy Metals (TF)}

TF is a parameter used to describe the mobility of heavy metals from soil to vegetable. TF was calculated to understand the risk associated with wastewater irrigation and consequent heavy metal accumulation in the edible portions of the test vegetables following a standard procedure (Cui et al., 2004):

$\mathrm{TF}=$

Concentration of metal in the edible part

Concentration of chemical element in soil under irrigation with wastewater

Transfer factor more than 1, mean that the plant is extracted the element from soil and concentrated in the tissues, where less than 1 indicates that plant is excluding the element from its tissues. TF for $\mathrm{Cu}$ ranged from 0.99 (celery-1) to 3.72 (chard) as shown in Table 3, the chard plant show highest TF for $\mathrm{Cu}$. The TF for $\mathrm{Zn}$ ranged from 1.38 (celery-1) to 10.12 (cress), the cress plant has highest TF for $\mathrm{Zn}$, because it is important for physiological processes, such as; Photosynthesis. The TF for $\mathrm{Pb}$ and $\mathrm{As}$ was show less than 1, indicates that the plant is excluding the element from its tissues (Lokeshwari et al., 2006). The cress show higher TF for elements; $\mathrm{Cu}$ and $\mathrm{Zn}$ as compared to other vegetables. This is because leafy vegetables have higher translocation and transpiration rate as compared to other vegetables in which transfer of metals from root to stem and then to fruit is longer which results in lower accumulation than leafy vegetables (Itanna, 2002).

\section{Health Risk Assessment of Heavy Metals}

Two international parameters include; target hazard quotient (THQ) (Wang et al., 2005), hazard quotient (HQ) (Sridhara et al., 2008; Chien et al., 2002) were used to study the effect of these vegetables to the human health. 


\section{Target Hazard Quotient (THQ) Method}

The potential health risks of heavy metal consumption through vegetables were assessed based on the target hazard quotient (THQ) method, which was described in detail by the United States Environmental Protection Agency. The THQ is calculated using the following equation (Wang et al., 2005):

\section{$T H Q=\left(E_{F} E_{D} F_{I R} C / R_{F D} W_{A B} T_{A}\right)^{* 10^{-3}}$}

where $\mathrm{E}_{\mathrm{F}}$ is the exposure frequency (350 days/year); $\mathrm{E}_{\mathrm{D}}$ is the exposure duration (70 years, equivalent to the average lifetime); $F_{I R}$ is the food ingestion rate (vegetable consumption values for adultsis 301.0 $\mathrm{g} /$ person/day); $\mathrm{C}$ is the metal concentration in the edible parts of vegetables $(\mathrm{mg} / \mathrm{kg}) ; \mathrm{R}_{\mathrm{f}} \mathrm{D}$ is the food reference dose for the metal $\left(\mathrm{mgd}^{-1}\right)$, the values of $\mathrm{R}_{\mathrm{f}} \mathrm{D}$ for heavy metals were taken from Integrated Risk Information System and Department of Environment, Food and Rural Affairs (DEFRA, 1999). $\mathrm{W}_{\mathrm{AB}}$ is the average body weight (55.9 $\mathrm{kg}$ for adults, for chins peoples) (Zheng et al., 2007) then, the average body weight for eastern peoples were estimated to be $67 \mathrm{~kg}$. The THQ of $\mathrm{Cu}, \mathrm{Pb}$ and $\mathrm{Zn}$ show high values more than 1 , while the THQ of As was below than 1 (Table

Table 1. Heavy metal concentrations $(\mathrm{mg} / \mathrm{kg})$ in study soil samples

\begin{tabular}{|c|c|c|c|c|}
\hline S.No. & $\mathrm{Cu}$ & $\mathrm{Pb}$ & As & $\mathrm{Zn}$ \\
\hline 1 & 21 & 3 & 4 & 48 \\
\hline 2 & 29 & 18 & 4 & 86 \\
\hline 3 & 22 & 18 & 5 & 51 \\
\hline 4 & 28 & 17 & 4 & 94 \\
\hline 5 & 21 & 5 & 6 & 46 \\
\hline 6 & 20 & 3 & 3 & 44 \\
\hline 7 & 24 & 15 & 5 & 49 \\
\hline 8 & 27 & 25 & 5 & 63 \\
\hline 9 & 27 & 10 & 5 & 68 \\
\hline 10 & 65 & 61 & 5 & 217 \\
\hline 11 & 66 & 39 & 6 & 197 \\
\hline 12 & 24 & 23 & 5 & 57 \\
\hline 13 & 26 & 10 & 6 & 57 \\
\hline 14 & 26 & 17 & 4 & 59 \\
\hline 15 & 28 & 12 & 7 & 67 \\
\hline 16 & 26 & 4 & 4 & 55 \\
\hline 17 & 25 & 3 & 7 & 51 \\
\hline 18 & 23 & 10 & 5 & 51 \\
\hline 19 & 27 & 8 & 5 & 57 \\
\hline 20 & 27 & 18 & 6 & 56 \\
\hline 21 & 28 & 17 & 6 & 59 \\
\hline 22 & 24 & 8 & 6 & 53 \\
\hline 23 & 24 & 3 & 6 & 54 \\
\hline 24 & 24 & 25 & 7 & 57 \\
\hline 25 & 25 & 16 & 6 & 62 \\
\hline 26 & 25 & 4 & 6 & 57 \\
\hline 27 & 23 & 3 & 7 & 52 \\
\hline 28 & 22 & 3 & 6 & 49 \\
\hline 29 & 26 & 5 & 6 & 63 \\
\hline 30 & 21 & 5 & 6 & 46 \\
\hline 31 & 21 & 3 & 6 & 45 \\
\hline 32 & 23 & 19 & 7 & 68 \\
\hline 33 & 39 & 38 & 8 & 119 \\
\hline Range & $20-66$ & 3-61 & $3-8$ & $44-217$ \\
\hline Average & 27.48 & 14.18 & 5.58 & 68.39 \\
\hline International shale* & 45 & 20 & 13 & 95 \\
\hline
\end{tabular}

*Source: Turekian and Wedepohl (28) 
Table 2. Heavy metal concentrations $(\mathrm{mg} / \mathrm{kg})$ in study vegetable samples

\begin{tabular}{|c|c|c|c|c|c|}
\hline S.No. & Vegetable & $\mathrm{Cu}$ & $\mathrm{Pb}$ & As & $\mathrm{Zn}$ \\
\hline 1 & Cress & 71.39 & 16.04 & 3.4 & 870.2 \\
\hline 2 & Leek & 87.39 & 11.46 & 1.8 & 311.2 \\
\hline 3 & Chard & 100.37 & 11.68 & 1.6 & 299.8 \\
\hline 4 & Celery-1 & 65.06 & 9.34 & 1.2 & 272 \\
\hline 5 & Celery-2 & 50.38 & 5.06 & 1.4 & 187.9 \\
\hline 6 & Celery-3 & 44.3 & 4.03 & 1 & 193.5 \\
\hline \multicolumn{2}{|c|}{ Range } & $44.3-100.37$ & $4.03-16.04$ & $1-3.4$ & $187.9-870.2$ \\
\hline \multicolumn{2}{|c|}{ Average } & 68.815 & 9.602 & 1.733 & 355.767 \\
\hline \multicolumn{2}{|c|}{ Safe limit* } & 73 & 0.3 & 0.43 & 100 \\
\hline
\end{tabular}

*Source: WHO/FAO (29)

Table 3. Transfer factor (TF) of chemical elements in the studied vegetable samples

\begin{tabular}{|c|c|c|c|c|}
\hline \multirow{4}{*}{$\begin{array}{c}\text { Heavy metals in } \\
\text { vegetable }\end{array}$} & $\mathrm{Cu}$ & $\mathrm{Pb}$ & $\mathrm{As}$ & $\mathrm{Zn}$ \\
\cline { 2 - 5 } & 71.39 & 16.04 & 3.4 & 870.2 \\
\cline { 2 - 5 } & 87.39 & 11.46 & 1.8 & 311.2 \\
\cline { 2 - 5 } & 100.37 & 11.68 & 1.6 & 299.8 \\
\cline { 2 - 5 } & 65.06 & 9.34 & 1.2 & 272 \\
\hline \multirow{4}{*}{\begin{tabular}{c} 
Heavy metals in \\
\cline { 2 - 5 } soil
\end{tabular}} & 50.38 & 5.06 & 1.4 & 187.9 \\
\cline { 2 - 5 } & 44.3 & 4.03 & 1 & 193.5 \\
\cline { 2 - 5 } & 29 & 18 & 4 & 86 \\
\cline { 2 - 5 } & 28 & 17 & 4 & 94 \\
\hline TF in cress & 24 & 25 & 6 & 63 \\
\hline TF in leek & 39 & 38 & 8 & 197 \\
\hline TF in chard & 3.46 & 0.89 & 0.85 & 10.12 \\
\hline TF in celery-1 & 3.12 & 0.67 & 0.45 & 3.31 \\
\hline TF in celery-2 & 2.10 & 0.47 & 0.32 & 4.76 \\
\hline TF in celery-3 & 1.14 & 0.24 & 0.20 & 1.38 \\
\hline Range & $0.99-3.72$ & $0.2-0.89$ & $0.13-0.85$ & $1.38-10.12$ \\
\hline Average & 2.68 & 0.55 & 0.45 & 5.07 \\
\hline
\end{tabular}

Table 4. Heavy metal target hazard quotient (THQ) values of the study vegetable samples

\begin{tabular}{|c|c|c|c|c|}
\hline Vegetable & $\mathrm{Cu}$ & $\mathrm{Pb}$ & $\mathrm{Zn}$ & As \\
\hline Cress & 7.69 & 19.74 & 12.50 & 0.004 \\
\hline Leek & 9.41 & 14.11 & 4.50 & 0.002 \\
\hline Chard & 10.81 & 14.38 & 4.31 & 0.002 \\
\hline Celery-1 & 7.01 & 11.50 & 3.91 & 0.001 \\
\hline Celery-2 & 5.43 & 6.23 & 2.50 & 0.002 \\
\hline Celery-3 & 4.77 & 4.96 & 2.78 & 0.001 \\
\hline Average & 7.52 & 11.82 & 5.08 & 0.002 \\
\hline
\end{tabular}


Table 5. Hazard quotient(HQ) for heavy metals in the study vegetable samples

\begin{tabular}{|c|c|c|c|c|}
\hline Vegetable & $\mathrm{Cu}$ & $\mathrm{Pb}$ & $\mathrm{Zn}$ & As \\
\hline Cress & 7.99 & 20.52 & 12.99 & 0.30 \\
\hline Leek & 9.78 & 14.66 & 4.65 & 0.16 \\
\hline Chard & 11.24 & 14.94 & 4.48 & 0.14 \\
\hline Celery-1 & 7.28 & 11.95 & 4.06 & 0.11 \\
\hline Celery-2 & 5.64 & 6.47 & 2.80 & 0.13 \\
\hline Celery-3 & 4.96 & 5.16 & 2.89 & 0.09 \\
\hline Average & 7.82 & 12.28 & 5.31 & 0.16 \\
\hline
\end{tabular}

Fig 1. The concentration of heavy metal in four types of vegetable samples

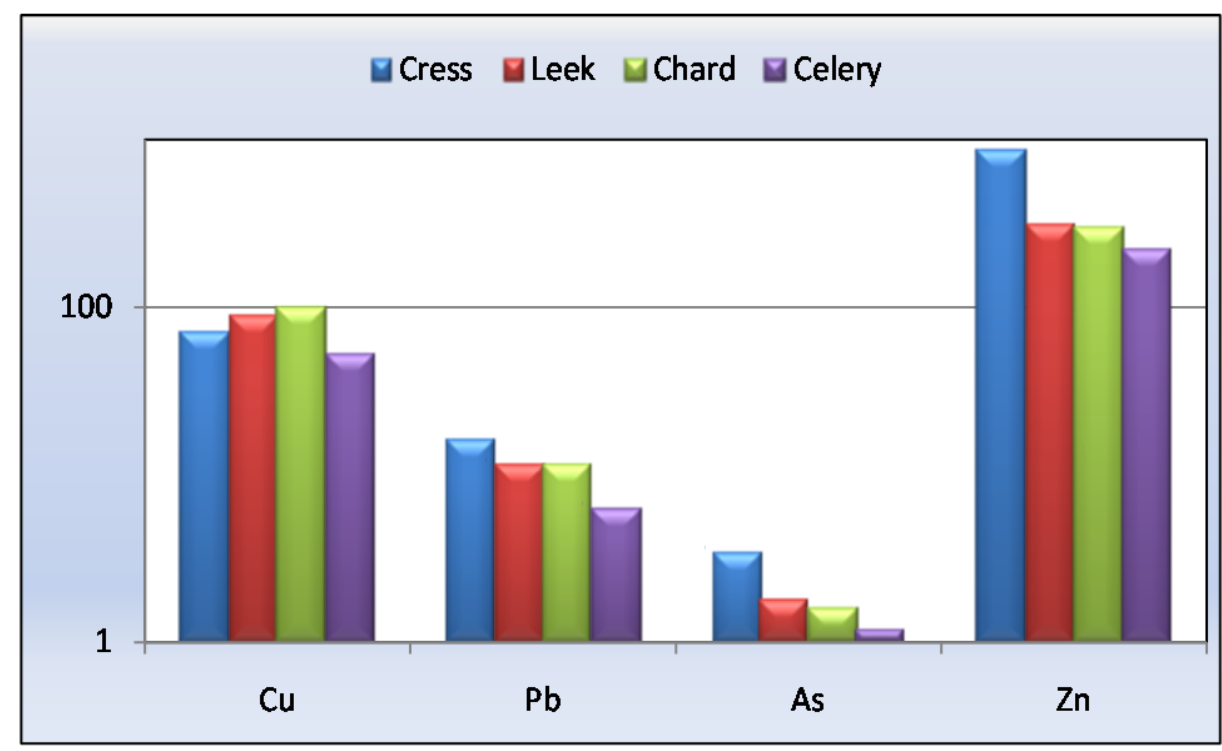

\section{Hazard Quotient (HQ)}

Risk of intake of metal-contaminated vegetables to human health was characterized by hazard quotient (HQ). This is a ratio of determined dose to the reference dose (RD). The population will pose no risk if the ratio is less than 1 and if the ratio is equal or greater than 1 then population will experience health risk. This risk assessment method has been used by researchers and proved to be valid and true. The following equation is used;

$\mathrm{HQ}=\left(\mathrm{D}_{\text {iv }}\right) \times\left(\mathrm{M}_{\text {plant }}\right) / \mathrm{R}_{\mathrm{f}} \mathrm{D} \times \mathrm{B}$

Where $\left(D_{i v}\right)$ is the daily intake of vegetables $(\mathrm{kg}$ person ${ }^{1}$ day $\left.^{-1}\right)$. The required amount of vegetables in our daily must be 300 to $350 \mathrm{~g}$ per person has been suggested by WHO guidelines (WHO, 1989), for this study, the daily intake of vegetable was estimated to be $300 \mathrm{~g} / \mathrm{day}$, (M) is the plant concentration of metal in vegetables $\left(\mathrm{mg} \mathrm{kg}^{-1}\right)$,
$\mathrm{R}_{\mathrm{f}} \mathrm{D}$ is the food reference dose for the metal $\left(\mathrm{mgd}^{-1}\right)$ and B is the human body mass $(\mathrm{kg})$. The HQ ratio for the studied vegetable samples are more than 1 in elements $\mathrm{Cu}, \mathrm{Pb}$ and $\mathrm{Zn}$, then the population is health risk and the toxicant may produce an adverse effect. While it is below 1 in the As (Table 5).

\section{Conclusion}

1. The studied soil samples show high concentration of the heavy metals. The concentration of these elements $\mathrm{Ag}, \mathrm{Ni}, \mathrm{Cd}, \mathrm{Bi}$ and $\mathrm{La}$ were higher than the standard shale with the averages $0.33,121.33,0.50,3.08$ and $9.77 \mathrm{mg} / \mathrm{kg}$, respectively. The other heavy metals e.g.; $\mathrm{Cu}$ (except samples 11 and 12 were higher than the standard), $\mathrm{Pb}$ (except samples 8, 10, 11, 12, 24 and 33 were higher than the standard), Zn (except samples 10, 11 and 33 were higher than the standard), Co, Mn, As, Sr, V, Cr, Ba and Ga show the concentrations that are lower than the standard shale 
2. Higher concentrations of the metal were detected in the studied vegetable samples than in the soil samples.

3. The studied vegetable samples show that the elements; $\mathrm{Cu}$ (except in samples 2 and 3), $\mathrm{Pb}, \mathrm{Zn}$ and As were in the highest average concentrations more than the World Health Organization limits, resulting from used wastewater for irrigation. The results of this study demonstrated that $\mathrm{Zn}$ was found in the highest concentration in the vegetables studied from among the investigated toxic heavy metals.

4. The transfer factor (TF) has high values in the elements; $\mathrm{Cu}$ and $\mathrm{Zn}$ with the averages 2.68 and 5.07, respectively. The cress shows higher TF for the elements; $\mathrm{Zn}, \mathrm{Cu}, \mathrm{Pb}$ and Asas compared with the other vegetables.

5. The target hazard quotient (THQ) values of $\mathrm{Cu}, \mathrm{Pb}$ and $\mathrm{Zn}$ elements in studied vegetable samples show high values more than 1 for both adults and children, while of As was below than 1 within acceptable limits. The hazard quotient (HQ) for the elements; $\mathrm{Cu}, \mathrm{Pb}$ and $\mathrm{Zn}$ in were more than 1 , suggesting that the population is health risk and the toxicant may produce an adverse effect, while it was below 1 in As. The elements will cause obvious adverse effects on human health, except As. The health risk and the toxicant may produce an adverse effect, was suggested not to be safe.

\section{References}

Abdollatif Gholizadeh, A., M. Ardalan, M.T. Mohammadi, H.M. Hosseini and N. Karimian. 2009. Solubility Test in Some Phosphate Rocks and their Potential for Direct Application in Soil. World App. Sci. J., 6(2): 182-190.

Chien, L.C., T.C. Hung, K.Y. Chaong, C.Y. Yeh, P.J. Meng and Shieh. 2002. Daily intake of TBT, Cu, $\mathrm{Zn}, \mathrm{Cd}$, and As for fishermen in Taiwan.Sci. Total arsenic, cadmium, chromium, copper, lead, mercury, Environ., 285: 177-185.

Cui, Y.J., Zhu, Y.G., Zhai, R.H., Chen, D.Y., Huang, Y.Z., Qiu, Y., Ling, J.Z. 2004. Transfer of metals from soil to vegetables in an area near a smelter in Nanning, China. Environ. Int., 30, $785 \mathrm{e} 791$. http://dx.doi.org/10.1007/BF02917176).

DEFRA (Department of Environment, Food and Rural Affairs). 1999. Total diet study-aluminium, arsenic, cadmium, chromium, copper, lead, mercury, nickel, selenium, tin and zinc. The Stationery Office, London.

Gupta, N., Khan, D.K., \& Santra, S.C. 2008. An assessment of heavy metal contamination invegetables grown in wastewater-irrigated areas of Titagarh, West Bengal, India. Bull. Environ. Contamination and Toxicol., 80, 115-118. Doi: 10.1007/ s00128-007-9327-z.

Hutchinson, T.C. and Meema, K.M. 1987. Lead, mercury, cadmium and arsenic in the environment, Scope 31, John Wiley and Sons, Chi Chester, 360p.

Itanna, F. 2002. Metals in leafy vegetables grown in Addis Ababa and toxicological implications. Ethiopian. J. Health Dev., 6: 295-302.

Jarup, L., 2003. Hazards of heavy metals contamination. Br. Med. Bull., 68: 167-182.

Khair, M.H., 2009. Toxicity and accumulation of copper in Nannochloropsis oculata (Eustigmatophycea, Heterokonta. World App. Sci. J., 6(3): 378-384.

Khan, S., Cao, Q., Zheng, Y. M., Huang, Y. Z., \& Zhu, Y. G. 2008. Health risks of heavy metalsin contaminated soils and food crops irrigated with wastewater in Beijing, China. Environmental Pollu., 152, 686-692. doi:10.1016/j.envpol.2007.06.056.

Lokeshwari, H. and GT. Chandrappa. 2006. Impact of heavy metal contamination of Bellandur Lake on soil and cultivated vegetation. Curr. Sci., 91: 620627.

Mapanda, F., Mangwayana, E.N., Nyamangara, J., \& Giller, K.E. 2005. The effect of long-termirrigation using wastewater on heavy metal contents of soils under vegetables in Harare, Zimbabwe. Agriculture Ecosystems \& Environ., 107, 151165.doi:10.1016/j.agee.2004.11.005.

Mello, D., J.P.F. 2003. Food safety: Contaminants and Toxins. CABI Publishing, Wallingford, Oxon, UK, Cambridge, MA. pp: 480.

Oliver, M.A. 1997. Soil and human health: a review. Eur. J. Soil Sci., 48: 573-592.

Pescod, M.B. 1992. Wastewater treatment and use in agriculture. FAO Irrigation and drainage Paper 47. Rome: Food and Agriculture Organization of the United Nations.

Rattan, R.K., Dutta, S.P., Chandra, S., Saharaan, N. 2002. Heavy metals in environmentsIndianscenario. Fertil News, 47:21-40.

Sharma, R.K., Agrawal, M., \& Marshall, F. 2007. Heavy metal contamination of soil and vegetables in suburban areas of Varanasi, India. Ecotoxicol. Environ. Safety, 66,258-266. doi:10.1016/ j.ecoenv.2005.11.007. 
Singh, K.P., Mohan, D., Sinha, S., \& Dalwani, R. 2004. Impact assessment of treated/ untreated wastewater toxicants discharged by sewage treatment plants on health, agricultural, and environmental quality in the wastewater disposal area. Chemosphere, 55, 227255.doi:10.1016/j.chemosphere.2003.10.050.

Sridhara Chary, N., C.T. Kamala and D. Samuel Suman Raj, 2008. Ecotoxicol. Environ. Safe, 69(3): 513524.

Steeland, K. And P. Boffetta. 2000. Lead and cancer in humans: where are we now? Am. J. Ind. Med., 38: 295-299.

Storelli, M.M. 2008. Potential human health risks from metals $(\mathrm{Hg}, \mathrm{Cd}$, and $\mathrm{Pb})$ and Polychlorinated Biphenyls (PCBS) Via Seafood consumption: Estimation of Target HazardQuotients (THQS) and Toxic Equivalents (TEQS). Food Chem. Toxicol., 46, 2782-2788.23.

Thornton, M. and E. Farago, 1997. Geochemistry of Arsenic. In: C. O. Abernathy, R. L. Calderon and W. R. Chappell, Editors, Arsenic, Exposure and Health Effects, Chapman \& Hall, London, pp: 27.

Turekian, K.K. and Wedepohl, K.H. 1961. Distribution of the elements in some major Units ofthe Earth's Crust, Bull. Geo. Soci. Amer., 72: 175-192.

Veeresh, H., Tripathy, S., Chaudhuri, D., Ghosh, B.C., Hart, B.R. and Powell, M.A. 2003. Changes in Physical and Chemical Properties of Three Soil
Types in India as a Result of Amendment with Fly Ash and Sewage Sludge. Environ. Geol., 43:513520.

Wang, X., T. Sato, B. Xing and S. Tao. 2005. Health risks of heavy metals to the general publicin Tianjin, China Via Consumption of vegetables and fish. Sci. Database, US Envrion. Protec. Agency. Total Environ., 350: 28-37.

WHO. 1992. Cadmium. Environmental Health Criteria, Geneva. Vol., 134.

WHO. 1992. Lead. Environmental Health Criteria, Geneva. Vol. 165.

WHO/FAO. 2007. Food Standard Programme Codex Alimentarius (ALINORM 07/30/13.Report of the Thirty Eight Session of the Codex Committee on Food Hygiene, Houston, United States of America.

Yadav, R.K., Goyal, B., Sharma, R. K., Dubey, S. K., \& Minhas, P.S. 2002. Post irrigationimpact of domestic sewage effluent on composition of soils, crops and ground water-a case study. Environ. Int., 28, 481-486. doi:10.1016/S0160- 4120(02)00070-3.

Zheng, N., Wang, Q., Zhang, X., Zheng, D., Zhang, Z., Znang, S. 2007. Population health risk due to dietary intake of heavy metals in the industrial area of Huludao City, China, Sci. Total Environ., 387, 96-104.

\section{How to cite this article:}

Sabah A. Ismail and Shwan M. Rashid. 2017. Health Risk Assessment of Heavy Metals for Population via Consumption of Vegetables Collected from Khassa River, Kirkuk City, Northern Iraq. Int.J.Curr.Res.Aca.Rev. 5(1), 104-110. doi: http://dx.doi.org/10.20546/ijcrar.2017.501.013 